\title{
Linking Early Childhood Education With Indigenous Education Using Gamification: The Case Of Maintaining Cultural Value And Identity
}

Catherine Chinyere Ukala, University of Port Harcourt, Nigeria Ogar G. Agabi, University of Port Harcourt, Nigeria

\begin{abstract}
Cultural values and identities remain the bench mark for national identity, cohesion, patriotism and harmonious coexistence in any society. The introduction of western education into west Africa created a weak bridge between the indigenous education and the western education which needs to be properly linked using curriculum harmonisation. This paper examines how far the curriculum of early childhood education in Nigeria link with indigenous education which is the child first point of learning. Four research questions guided the study. The study adopted a descriptive survey design with a population of 655 public primary schools that house early childhood centers spread across the 23 local government areas of Rivers State. A sample size of 164 head teachers in early childhood centers was drawn using stratified random sampling technique representing 25\% of the population. Questionnaire which was validated was used as the instrument and the reliability yielded an index of 0.81. Mean and rank order scores were used to answer the research questions. The findings revealed among others, that methodologies that used gamification can be linked with early childhood education and indigenous education. These include storytelling, riddles, animal clowning, demonstration, stone counting, and local farm tools by the teachers. This implies that the teachers are aware of the ways gamification can be used to link early childhood education with indigenous education but do not use most of these methods probably it is not highlighted in their scheme of work. Based on the findings, the researchers recommended that the western curriculum should be developed base on an indigenous knowledge of early childhood in teacher training institution curriculum for early childhood education.
\end{abstract}

Keywords: Early Childhood Education, Indigenous Education, Gamification, Cultural Value And Identity

\section{INTRODUCTION}

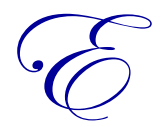

ducation is a dynamic instrument of change. It is the bedrock of every society for meaningful development and growth. It is the vehicle for fostering natural growth, cohesion, and peaceful coexistence especially in a pluralistic society with diverse ethnic groups. It is the process of facilitating learning, knowledge, skills and values. According to Dictionary.com (2015) it is the process of imparting or acquiring general knowledge, developing the powers of reasoning and judgment, and generally of preparing oneself intellectually for mature life. Federal Republic of Nigeria (2004) in National Policy on Education sees it as an instrument "par excellence" for effecting national development. It assists in physical, mental, moral and emotional development of the child.

The child is an important factor in the educational system of a nation as raw materials are very essential commodities for the operation of industries. Nigeria is not an exception though the manipulation of this educational resource may assume a more complex dimension here. It is an acceptable concept that "the child" is the core of a country's educational system. It will not be out of place for one to say that "the child" in this context embraces all those within the early childhood-age that is from the age of two to five years. This paper is concerned with mainly children of the above age bracket. It deals with linking their education with indigenous education using gamification for the maintenance of cultural values and identity. 


\section{AN OVERVIEW OF RELATED CONCEPTS}

\section{Concept of Early Childhood Education}

Early childhood education is that aspect of education provided for children before the primary school age. It includes the crèche, the nursery and the kindergarten (Federal Republic of Nigeria, 2004). It is an undeniable fact that this aspect of education is the bedrock upon which all other levels of education are anchored. The level of access a child has to quality early childhood education will definitely determine the ease with which the child can advance through other levels of education (The World Bank 2000; Federal Ministry of Health, 2004).

Section 2: 13, of the National Policy on Education stipulates that the purpose of pre-primary education shall be to:
a) affect a smooth transition from the home to the school;
b) prepare the child for the primary level of education
c) provide adequate care and supervision for the children while their parents are at work;
d) inculcate social norms;
e) inculcate in the child the spirit of inquiry and creativity through the exploration of nature, the environment, art, music and playing with toys, etc.;
f) develop a sense of co-operation and team spirit;
g) learn good habits, especially good health habit; and teach the rudiments of numbers, letters, colours, shapes, forms, etc. through play.

However, in Section 14 it emphasized that the medium of instruction is principally the mother-tongue or the language of immediate community and to achieve this there would be a development of the orthography of many more Nigerian languages and production of textbooks in Nigerian languages. That the main method of teaching the child at this level shall be through play with the attendant teaching pupil ratio of 1:25 respectively.

Unfortunately, this aspect of education has never received any serious government attention. Prior to the introduction of Universal Basic Education Programme (UBE), Government policies on education in Nigeria were silent on early childhood education. At the best, government's responsibility was limited to accreditation and licensing and control of private proprietors engaged in the provision of early childhood education. It is only the private proprietors of schools that have always provided early childhood education as part of their school programme. This means that the majority of children in public schools have no access to early childhood education. Moreover, government did not have any input into the curriculum or method of instruction of the private schools that are responsible for the implementation of early child education at this level.

In Rivers State, the situation had a slight variation. The first military administrator of Rivers State as a way of demonstrating commitment to early childhood education established three pre-primary educational institutions. These were the Sea-bed, the Sea-shell and PABOD schools (Rivers State Ministry of Education, 2007). Efforts to spread this initiative across all the local government areas never materialized until the government was changed. Unfortunately, subsequent government never considered it so much of a public responsibility, but saw it as educational services that the private proprietors could handle better.

However, with the introduction of the Universal Basic Education (UBE) early childhood education is now recognized as an integral aspect of the UBE curriculum (Federal Republic of Nigeria, 2004). In other words, the full implementation of the UBE requires the inclusion of early childhood education as part of the UBE programme. This is even in line with international best practices (Young, 2002).

In support of this, Federal Ministry of Education in its policy stated that, government responsibilities in early childhood education are to provide quality teachers' training centers for early childhood education, contribute to suitable curriculum development, supervise and control quality of school delivery and establish pre-primary sectors in existing public schools using the local language or local language of immediate community as a medium of instruction (Federal Ministry of Education, 2004). 


\section{Concept of Early Childhood Indigenous Education}

Indigenous early childhood education is that education that focuses on teaching children from birth on knowledge that have been handed down from one generation to another through oral tradition. This knowledge is imbedded in the language and traditions that are evident in such processes as storytelling, games, idiomatic expression, parables, riddles, proverbs, ceremonies, rites, verbal and nonverbal communication such as sign language, music, songs, dance, masquerade displays among others. Practically these methods of imparting knowledge are done through imitating and watching the elders. It also emphasized on practical learning as part of the culture of the indigenous society. For example, if a child is born into a family of a herbalist, canoe builder or pottery making or even basket weaving, at age six or seven the child must have mastered the nitty gritty of the skills of the family business, even though the acquisition of these skills have no special time or place where it takes place. These skills enable children to grow up and become functional member of the society they belong to, especially in the area of socio-economic activity of the individuals and the development of the society at large. As a result, skills imparted were relevant to the socio-economic activities of the people and self reliance.

Moreover, in Indigenous early childhood education, children belong to the whole community or clan. So children depend on the community for upbringing. A child who misbehaves could be corrected on the spot by any adult. This type of education has no paper qualification. However, the child graduates with pomp and pageantry when he has been able to practice effectively and efficiently whatever skill he had learnt as a child. The entire community knows that if the child does not have competence in the skills no one would patronize him and it would even bring shame to the family. In support of this assertion, Kerry (2011) opined that African indigenous education is the nature; locally develop form of bringing up the youngsters by older and more experienced members of the society. It went on to say that it is the passing down of knowledge, skills, attitude of the tribe from elders to the children by oral instructions and practical activities. He also emphasizes the characteristics of the indigenous education as follows:

- community oriented that geared towards solving the problems of the community.

- Activity oriented - as instructional activities were directed towards the social life of the community, so as to prepare the learners to fit into their community.

- It is also localized to a particular region. Originating or occurring naturally in a particular place or native environment.

On the other hand, Mushi (2009) defined African indigenous education as a process of passing inherited knowledge, skills, cultural traditions, norms, and values of the tribe from one generation to the other. With these, one could see that indigenous knowledge is a continuous learning process from childhood to old age. Even as an adult any act of indiscipline would be frowned at by immediate family members, the clan and the community at large. Mushi (2009) also asserted that the indigenous education was essentially part of life and not separated from the societal culture. This invariably gives children sense of belonging and also makes them to be patriotic. These traditional cultural values are also essential for the protection and development of children. With these, children grow up with pride when they are identified with their ancestral roots. In indigenous education integrity and discipline are highly prized as priority. It is the foundation of education for self-reliance and if one's integrity or character is questionable one will have oneself to blame and bring shame, to one's family and community and invariably be isolated from his people. With these we could perceived that the indigenous education is embedded in the culture of the people. Culture is a set of shared values, beliefs, attributes and customs that set the people apart from other groups and dictate their way of life. The cultural value system of the indigenous education was indeed good and guided the people to have a very high ethical code of conduct that emancipated from the natural laws of justice. It taught them respect for one another, other peoples' property, mutual respect, togetherness and gave them a sense of security when compared with the insecurity issues we are having in today's' modern society. Though, it lacks technological exchange, and gender bias, the two have to be merged to bring out the best in the child. According to Bruner (1964:93) in Maxwell (2015) in his "Genius Principles" stated that "Games go a long way to getting children involved in understanding language, social organization, and the rest, introduced the idea of theory to these phenomena." 


\section{Curriculum for Early Childhood Education}

A curriculum is a planned set of course of study in a school system. It is synonymous with syllabus. According to Ebert II, Ebert and Bentley (2013) curriculum refers to the means and materials with which students interact for the purpose of achieving identified educational goals. They went on to stress that curriculum is that part of the planned activities that directly affect students and a plan that keeps the goal in focus. However other variables that crop up during this learning process are regarded by most educationist as hidden curriculum or the contemporary curriculum.

However, in early childhood education, there are theories that guide the development of curriculum at this level of education. These educational theories among others are those of Piaget, Waldorf and Montessori. However, the most popular in used in most schools is that of Montessori.

According to Piaget, children learn by watching and doing and that the sensory motor stage lasts from birth to about age two. Children at this level try to explore and understand their immediate environment through physical actions. Shell (n.d) using Montessori theory opined that children have difficulties separating the real life from fantasy. As a result, the activities children do in school should be realistic oriented. Waldorf emphasized on play as the means by which a child can make sense of his immediate environment using natural toys and his creative imagination also Piaget agreed that play is a reality which the child is disposed to believe in and learn through experiences. With these, we can all agree that children learn better by touching, seeing, smelling, exploring than by just listening. Also they have to be in a conducive environment that is not crowded.

\section{Statement of the Problem}

In most homes in Nigeria today, children cannot speak their native dialect nor understand the indigenous verbal and non verbal expressions, sign languages, idiomatic expressions, local parables, cultural values, norms among others of their ethnic groups. Most Nigerian children of today seem to be hanging in between two worlds they do not quite understand. The rate of indiscipline and youth restiveness in the name of militancy, "bokoharam," "area boys" among others which were alien to the Nigerian society is on the increase. It is not even known what will become of some of the ethnic languages of more than twenty-six ethnic groups in the nearest future. Early childhood education is supposed to link the indigenous education with its western curriculum content in such a way that it will strike a harmonious balance on what the child is supposed to be imparted with and also identify with. The researcher is there bothered about ways of linking indigenous education with early childhood education using gamification.

\section{AIM AND OBJECTIVES OF THE STUDY}

The aim of the study is to investigate ways of linking indigenous education with early childhood education using gamification in maintaining cultural value and identity in Rivers State.

Based on the above problems, this study was designed to achieve the following objectives:

- find out the type of curriculum designed for early childhood education in maintaining cultural value and identity in Rivers State, Nigeria

- investigate ways the use of gamification can be linked to early childhood education in maintaining cultural value and identity in Rivers State.

- Find out the pedagogy/methodology that is specific to the needs of indigenous education through gamification in early childhood education in maintaining cultural value and identity in Rivers State.

- Determine the challenges inhibiting the linkage of indigenous education using gamification in early childhood education in maintaining cultural values and identity in Rivers State. 


\section{RESEARCH QUESTIONS}

The following research questions were raised

- What type of indigenous education curriculum is designed for early childhood education in maintaining cultural value and identity in Rivers State?

- In what ways can the use of gamification be linked with early childhood education and indigenous education in maintaining cultural value and identity in Rivers State?

- What is the pedagogy/methodology in early childhood education that is specific to the needs of indigenous education through gamification in maintaining cultural value and identity in Rivers State?

- What are the challenges inhibiting the linkage of indigenous education through gamification in early childhood education in maintaining cultural value and identity in Rivers State?

\section{METHODOLOGY}

This is a descriptive survey study. The population comprised all 655 public primary schools that house early childhood centers spread across the 23 local government areas of Rivers State. All the school head teachers are the respondents. The stratified random sampling technique using $25 \%$ of the population was used to draw a sample size of 164 head teachers in early childhood centers.

A self-designed 41 items instrument titled "Linking Early Childhood Education with Indigenous Education using Gamification Questionnaire (IECEWIEUGQ) was validated for the study. The instrument was structured after the four-point likert type scale of Strongly Agreed 4, Agreed 3, Disagreed 2 and Strongly Disagreed 1. The reliability testing of the instrument was done using the Cronbach's alpha method which yielded a co-efficient of 0.81 indicating a high-reliability index. The instrument was administered personally by the researchers with the assistance of some head teachers who were sufficiently briefed for the assignment. The various research questions were analyzed using mean and rank order statistics.

\section{DATA ANALYSIS}

\section{Research Question One}

What type of curriculum is designed for early childhood education in Rivers State for maintenance of value and identity? 
Table 1.Weighted mean and rank order statistics on the types of curriculum designed for early childhood education in Rivers State for maintenance of value and identity.

\begin{tabular}{|c|c|c|c|c|}
\hline $\mathbf{S} / \mathbf{N}$ & $\begin{array}{l}\text { Types of curriculum designed for early childhood education } \\
\text { for maintenance of value and identity include: }\end{array}$ & $\overline{\mathbf{X}}$ & Rank & Remarks \\
\hline a) & $\begin{array}{l}\text { The curriculum is based on Montessori theory on early childhood } \\
\text { education. }\end{array}$ & 3.05 & $2^{\text {nd }}$ & Agreed \\
\hline b) & The curriculum is based on Piaget theory on early childhood education. & 3.56 & $1^{\text {st }}$ & Agreed \\
\hline c) & The curriculum is based on Waldorf theory on early childhood education. & 1.83 & $8^{\text {th }}$ & Disagreed \\
\hline d) & The curriculum is based on the above three mentioned theory. & 1.91 & $7^{\text {th }}$ & Disagreed \\
\hline e) & $\begin{array}{l}\text { The curriculum is designed based on Indigenous early childhood education } \\
\text { of Rivers State. }\end{array}$ & 1.95 & $6^{\text {th }}$ & Disagreed \\
\hline f) & $\begin{array}{l}\text { The curriculum is designed based on the Indigenous education of the } \\
\text { southern region of Nigeria. }\end{array}$ & 2.00 & $4^{\text {th }}$ & Disagreed \\
\hline g) & $\begin{array}{l}\text { The curriculum is designed based on the selected Indigenous education of } \\
\text { some region in Nigeria. }\end{array}$ & 2.40 & $3^{\text {rd }}$ & Disagreed \\
\hline h) & $\begin{array}{l}\text { The curriculum is designed based on the combination of Montessori, } \\
\text { Piaget, Waldorf and Indigenous early childhood of Rivers State. }\end{array}$ & 1.96 & $5^{\text {th }}$ & Disagreed \\
\hline i) & $\begin{array}{l}\text { The curriculum is designed based on the combination of Montessori, } \\
\text { Piaget, Waldorf and Indigenous education on early child education of } \\
\text { southern region of Nigeria. }\end{array}$ & 1.74 & $10^{\text {th }}$ & Disagreed \\
\hline j) & $\begin{array}{l}\text { The curriculum is designed based on the combination of Montessori, } \\
\text { Piaget, Waldorf and others with the selected Indigenous early childhood } \\
\text { education of all the regions Nigeria as a whole. }\end{array}$ & 1.77 & $9^{\text {th }}$ & Disagreed \\
\hline \multirow{2}{*}{\multicolumn{2}{|c|}{ Aggregate Mean $(\bar{x})$}} & 22.17 & & \\
\hline & & 2.22 & & \\
\hline
\end{tabular}

Table 1 shows that items with serial numbers a and $b$ have their various mean values above the mean criterion value of 2.50 and were therefore agreed by the head teachers as types of curriculum designed for early childhood education in Rivers State for maintenance of value and identity. While items with serial numbers c,d,e,f,g,h,i and $\mathrm{j}$ have their various mean values below the criterion mean of 2.50 and were therefore disagreed by the head teachers as types of curriculum designed for early childhood education in Rivers State for maintenance of value and identity.

\section{Research Question Two}

In what ways can the use of gamification be linked with early childhood education and indigenous education in maintaining of value and identity in Rivers, Nigeria? 
Table 2.Weighted mean and rank order statistics on the ways the use of gamification can be linked with early childhood education and indigenous education for maintenance of value and identity

\begin{tabular}{|c|c|c|c|c|}
\hline $\mathbf{S} / \mathbf{N}$ & Items & $\overline{\mathbf{X}}$ & Rank & Remarks \\
\hline a) & Stories are modified into plays for the children to act upon. & 3.36 & $5^{\text {th }}$ & Agreed \\
\hline b) & Games are linked through the use of riddles. & 3.55 & $2^{\text {nd }}$ & Agreed \\
\hline c) & Animals are clown on the children to act on indigenous folk tale stories & 3.05 & $7^{\text {th }}$ & Agreed \\
\hline d) & $\begin{array}{l}\text { Songs are taught by using demonstration explaining the concept of the } \\
\text { songs to the children. }\end{array}$ & 3.43 & $4^{\text {th }}$ & Agreed \\
\hline e) & Numbers are taught through the use of stones in counting. & 3.01 & $8^{\text {th }}$ & Agreed \\
\hline f) & Farming are taught by going to school to demonstrate using farming tools. & 3.73 & $1^{\text {st }}$ & Agreed \\
\hline g) & Animal stories are taught mimicking the various sounds they make. & 3.46 & $3^{\text {rd }}$ & Agreed \\
\hline h) & Children are taught to think outside the indigenous box abacus. & 2.91 & $9^{\text {th }}$ & Agreed \\
\hline i) & Aquatic life is taught by taking children to stream. & 3.25 & $6^{\text {th }}$ & Agreed \\
\hline j) & Wild life is taught by taking children to the zoo. & 2.14 & $10^{\text {th }}$ & Agreed \\
\hline \multirow{2}{*}{\multicolumn{2}{|c|}{ Aggregate Mean $(\bar{x})$}} & 31.89 & & \\
\hline & & 3.19 & & \\
\hline
\end{tabular}

Table 2 reveals that items with serial numbers a,b,c,d,e,f,g,h,i and $\mathrm{j}$ have various means above the mean criterion value of 2.50. As a result, all the Head teachers agreed that the use of gamification is imperative in early childhood education for the maintenance indigenous value and identity.

\section{Research Question Three}

What is the pedagogy/methodology in early childhood education that is specific to the needs of indigenous education through gamification in maintaining cultural value and identity in Rivers State, Nigeria?

Table 3.Weighted mean and rank order statistics on the pedagogy/methodology can be used in early childhood education that is specific to the needs of indigenous education through gamification for maintenance of value and identity

\begin{tabular}{c|l|c|c|c}
\hline S/N & ITEMS & $\overline{\mathbf{X}}$ & Rank & Remarks \\
\hline a) & Demonstration method. & 3.63 & $3^{\text {rd }}$ & Agreed \\
\hline b) & Expository method. & 3.31 & $5^{\text {th }}$ & Agreed \\
\hline c) & Exploratory method. & 3.10 & $7^{\text {th }}$ & Agreed \\
\hline d) & Manipulative method to make sense of the lesson taught. & 3.17 & $6^{\text {th }}$ & Agreed \\
\hline e) & Rote memorization. & 3.80 & $2^{\text {nd }}$ & Agreed \\
\hline f) & Instructional. & 3.53 & $4^{\text {th }}$ & Agreed \\
\hline g) & Lecture method. & 1.92 & $9^{\text {th }}$ & Disagreed \\
\hline h) & Field trips (excursion). & 3.09 & $8^{\text {th }}$ & Agreed \\
\hline i) & Game. & 3.92 & $1^{\text {st }}$ & Agreed \\
\hline \multicolumn{2}{|l}{ Aggregate Mean $(\overline{\mathrm{x}})$} & 29.47 & 3.27 & \\
\hline
\end{tabular}

Table 3 shows that items with serial numbers a,b,c,d,e,f,h and i have their various mean values above the mean criterion of 2.50. This suggests that the indigenous methodology is specifically necessary for teaching and learning at this level of education. Item with serial number $g$ has mean below the mean criterion value of 2.50 and is not agreed 
by the head teachers as the pedagogy/methodology that can be used in early childhood education that is specific to the needs of indigenous education through gamification for maintenance of value and identity.

\section{Research Question Four}

What are the challenges inhibiting the linkage of indigenous education through gamification in early childhood education for maintenance of value and identity?

Table 4. Weight mea and rank order statistics on the challenges inhibiting the linkage of indigenous education through gamification in early childhood education for maintenance of value and identity

\begin{tabular}{|c|c|c|c|c|}
\hline $\mathbf{S} / \mathbf{N}$ & ITEMS & $\overline{\mathbf{X}}$ & Rank & Remarks \\
\hline a) & $\begin{array}{l}\text { Difficulty involved in translating the early childhood curriculum into } \\
\text { indigenous languages. }\end{array}$ & 3.41 & $4^{\text {th }}$ & Agreed \\
\hline b) & Heterogeneous nature of early childhood curriculum. & 3.20 & $7^{\text {th }}$ & Agreed \\
\hline c) & Lack of indigenous instructional materials. & 3.01 & $8^{\text {th }}$ & Agreed \\
\hline d) & Lack of early childhood indigenous trained teachers. & 2.99 & $9^{\text {th }}$ & Agreed \\
\hline e) & $\begin{array}{l}\text { Inadequate supply of minders for early childhood education from the } \\
\text { community. }\end{array}$ & 2.94 & $12^{\text {th }}$ & Agreed \\
\hline f) & Lack of funds from stakeholders. & 3.26 & $5^{\text {th }}$ & Agreed \\
\hline g) & Lack of participation from elders of the community. & 3.80 & $1^{\text {st }}$ & Agreed \\
\hline h) & Lack of common indigenous language. & 3.23 & $6^{\text {th }}$ & Agreed \\
\hline i) & Lack of early childhood indigenous facilities. & 3.70 & $2^{\text {nd }}$ & Agreed \\
\hline j) & Attitude of most parents towards indigenous education. & 2.98 & $10^{\text {th }}$ & Agreed \\
\hline k) & Lack of spacious classroom. & 3.66 & $3^{\text {rd }}$ & Agreed \\
\hline 1) & Lack of playground & 2.96 & $11^{\text {th }}$ & Agreed \\
\hline \multirow{2}{*}{\multicolumn{2}{|c|}{ Aggregate Mean $(\bar{x})$}} & 39.14 & & \\
\hline & & 3.26 & & \\
\hline
\end{tabular}

Table 4 reveals that items with serial numbers a, b, c, d, e, g, h, i, j, k and 1 have their various mean values above the mean criterion value of 2.50 . With this, all the head teachers agreed that these are the challenges inhibiting the linkage of indigenous education through gamification in early childhood education for maintenance of value and identity.

\section{DISCUSSION OF FINDINGS}

The findings of this study revealed that the curriculum content designed for early childhood education in Rivers State are not in harmony with indigenous early childhood education of the Nigerian society. This content of the curriculum varied from one center to another. The curriculum being used is based on Montessori and Piaget theories on early childhood education. However, this is not in line with what the Nigerian Policy on Education stipulated. According to the policy, it stated that the curriculum is based on the culture and language of the child's immediate environment (Federal Republic of Nigeria, 2004).

The findings also revealed that ways the use of gamification can be linked with early childhood education and indigenous education are among others: storytelling, riddles, animal clowning, demonstration, stone counting, local farm tools by the teachers. This implies that the teachers are aware of the ways gamification can be used to link early childhood education with indigenous education but they do not use most of these methods probably it is not highlighted in their scheme of work. This agrees with the findings of Maxwell (2015) in Bruner (1964) which reveals that game goes a long way to getting children involved in understanding language, social organization, and the rest; they also introduce the idea of theory to these phenomena. This is also in line with the findings of Montessori in Maxwell (2015) that when a Mozart or a Davinci is put at sea and on the right course by age 2, the child will learn to steer himself and if a rudder is missing he creates one.

The methodology that can be used in early childhood education that is specific to the needs of indigenous education using gamification is demonstration, exposition, exploration, manipulation, rote memorization, use of indigenous 
materials, field trips excursion among others as agreed by the respondents. However, the study and visitation to early childhood centers revealed that teachers are still using rote memorization and other older methods that makes learning an abstract to the child. This is because, there are hardly well-trained teachers to handle this level of education in Rivers State.

The study finally revealed that many challenges seem to inhibit the linkage of indigenous education using gamification in early childhood education in Rivers State. These will be highlighted since time will not permit us to exhaust the list in this paper. These are as follows. Since government pronouncement and recognition of early childhood education as an aspect of the UBE (Universal Basic Education)(Federal Republic of Nigeria, 2004), government has not as agreed provided quality teachers training centers for early childhood education nor contribute to suitable curriculum development, supervise and control quality of school delivery in the existing centers. As a result, the curriculum content lacks relevance to the societal needs.

- There is no community and parent participation in linking indigenous education through gamification in early childhood in Rivers State.

- There is lack of funding from all the stakeholders in early childhood education programme in Rivers State.

- Basic and indigenous infrastructural facilities are lacking in this level of education in Rivers State.

- Difficulty involve in translating the early childhood curriculum into indigenous languages is also a problem in linking indigenous education through gamification in early childhood education in Rivers State.

- Inadequate supply of minders for early childhood education from the community.

- Urbanization makes the use of local language problematic as a result the language of immediate environment causes a problem.

\section{CONCLUSION}

The relevance of Indigenous early childhood education cannot be overemphasized for it is the foundation of education for self-reliance, respect for human life and property, togetherness, high ethical code of conduct and could be used to solve the emerging problem of youth restiveness and other ills facing our country today. The combination of Indigenous early childhood education and western early childhood curriculum at the right-start give a proper foundation to harness the potentials, right values and attitude to these youngsters as they grow up in the competitive world of the $21^{\text {st }}$ century.

\section{RECOMMENDATIONS}

Based on this study the following recommendations are made:

(1) The western curriculum should be developed on an indigenous base at the teacher training institutions for early childhood education.

(2) There should be sensitization of capacity building programme for early childhood education using gamification.

(3) Government should put the funding of all the resources needed for early childhood education in their priority list when budgeting for education.

(4) Early childhood education department should be implemented in all the universities running programme in education.

(5) Research should be encouraged on Indigenous early childhood education so that some Nigerian cultural heritage and valves would not go extinct.

(6) Indigenous toys and the normal toys for early childhood education should be incorporated into games to enable children have analytical mind and also think outside the box.

(7) Right curriculum should be developed by experts linking Indigenous early childhood education using gamification in consonance to the contemporary realities of what is happening in our society. 


\section{AUTHOR BIOGRAPHIES}

Catherine Chinyere Ukala specialized on early childhood education and planning. She is a lecturer in the Department of Educational Management, Faculty of Education, University of Port Harcourt, Rivers State, Nigeria. She is married with children.

Ogar G. Agabi specialized on Educational Planning. He is a senior lecturer in the Department of Educational Management, Faculty of Education, University of Port Harcourt, Rivers State, Nigeria. He is married with children.

\section{REFERENCES}

Bruner, J. S. (1964). The course of cognitive growth. American Psychologist, 19(1), 1-15.

Dictionary.com (2015). Education. Retrieved $2^{\text {nd }}$ June, 2015 from dictionary.reference.com/browse/education? $\mathrm{s}=\mathrm{t}$.

Ebert II, E. S., Ebert, C. \& Bentley, M. L. (2013). Curriculum definition. Retrieved from http://www.education.com/reference/article/curriculum-definition/ Echlin.

Federal Ministry of Education (2007). The need of the total child. Port Harcourt: Rivers State Universal Basic Education Board.

Federal Ministry of Health (2004). Promoting good caring practices for our children: Helping Uganda's child achieve their full potentials. A Participating Planning Manual for the Uganda Nutrition and Early Childhood Development Project Book 14.

Federal Republic of Nigeria (2004). National Policy on Education ( $4^{\text {th }}$ ed.) Lagos: Nigerian Educational Research and Development Council.

Kerry, S. (2011). History of education in East Africa. Retrieved May $20^{\text {th }}$ from http://samwiterson.blogspot.com/2011/07/historyof-education-in-east-africa.html?m=1

Maxwell, W. (2015). The first public proclamation of the "genius principles". (Public Lecture) Port Harcourt: University of Port Harcourt and Ignatius Ajuru University of Education, Nigeria.

Mushi, P.A.K. (2009). History of education in Tanzania. Dar-es-Salam: Dar-es-Salam University Press.

Shell, B. (n.d). AA Look at Waldorf and Montessori Education in the Early Childhood Programs. Retrieved from http://www.bayouvillageschool.org/uploads/5/1/2/1/5121407/alookatwaldorfandmontessori.pdf

The World Bank, (2000, September). Showcasing early childhood care and development: Innovation and Application in Africa. International Conference on Early Childhood Care and Development (ECCD) held at Uganda, International Conference Centre, Kampala, Uganda, (1999) Washington, D.C. World Bank.

Young M.E. (2002). From early child development to human development: Investing in our children's future (10 $0^{\text {th }}$ Ed.) Washington, D.C. The World Bank. 